\title{
A Bibliometric Analysis of the Global Research Trend in Child Maltreatment
}

\author{
Bach Xuan Tran $1,2,3, *,+\left({ }^{\circ}\right)$, Thang Van Pham ${ }^{4,5,+(B)}$, Giang Hai Ha ${ }^{6}$, Anh Toan Ngo ${ }^{1,7}$, \\ Long Hoang Nguyen ${ }^{8}$, Thuc Thi Minh Vu ${ }^{9}, \mathrm{Ha}$ Ngoc Do ${ }^{10}, \mathrm{Vu}$ Nguyen ${ }^{11}$, \\ Anh Tuan Le Nguyen ${ }^{1}{ }^{(\mathbb{D})}$, Tung Thanh Tran ${ }^{6}$, Nu Thi Truong ${ }^{6}$, Vuong Quan Hoang ${ }^{12,13(\mathbb{D})}$ \\ Tung Manh Ho ${ }^{14}$, Nhue Van Dam ${ }^{15}{ }^{(\mathbb{D}}$, Thu Trang Vuong ${ }^{16}$, Hung Quang Nguyen ${ }^{17}$, \\ Huong Thi Le ${ }^{1}$, Hoa Thi Do ${ }^{1}$, Mackenzie Moir ${ }^{18}$, Yoko Shimpuku ${ }^{19}{ }^{\mathbb{D}}$, Meghnath Dhimal ${ }^{20,21}$, \\ Shalini Subash Arya ${ }^{22}$, Tu Huu Nguyen ${ }^{3}$, Suraj Bhattarai ${ }^{23}$, Carl A. Latkin ${ }^{2}$, Cyrus S.H. Ho ${ }^{24}$ \\ and Roger C.M. Ho ${ }^{25}$
}

1 Institute for Preventive Medicine and Public Health, Hanoi Medical University, Hanoi 100000, Vietnam; ngotoananh85@gmail.com (A.T.N.); dennguyenle@gmail.com (A.T.L.N.); lethihuong@hmu.edu.vn (H.T.L.); dothihoa1954@yahoo.com (H.T.D.)

2 Bloomberg School of Public Health, Johns Hopkins University, Baltimore, MD 21205, USA; carl.latkin@jhu.edu

3 Vietnam Young Physician Association, Hanoi 100000, Vietnam; huutu85@gmail.com

4 Department of Pediatrics, Hanoi Medical University, Hanoi 100000, Vietnam; tsbsthang@yahoo.com

5 Department of Emergency Medicine, Vietnam National Children's Hospital, Hanoi 100000, Vietnam

6 Institute for Global Health Innovations, Duy Tan University, Da Nang 550000, Vietnam; giang.ighi@gmail.com (G.H.H.); tung.ighi@gmail.com (T.T.T.); truongnu.ighi@gmail.com (N.T.T.)

7 National Hospital of Obstetrics and Gynecology, Hanoi 100000, Vietnam

8 Department of Public Health Sciences, Karolinska Institutet, SE-171 77 Stockholm, Sweden; longnh.ph@gmail.com

9 Center for Research and Training, Tam Anh Hospital, Hanoi 100000, Vietnam; vuminhthuc2010@yahoo.com.vn

10 Youth Research Institute, Ho Chi Minh Communist Youth Union, Hanoi 100000, Vietnam; ngochayri@gmail.com

11 Department of Surgery, Hanoi Medical University Hospital, Hanoi 100000, Vietnam; nguyenvu@hmu.edu.vn

12 Center for Interdisciplinary Social Research, Thanh Tay University, Hanoi 100000, Vietnam; qvuong@ulb.ac.be

13 Solvay Brussels School of Economics and Management, Centre Emile Bernheim, Université Libre de Bruxelles, Brussels B-1050, Belgium

14 Institute of Philosophy, Vietnam Academy of Social Sciences, Hanoi 100000, Vietnam; tung.ho@wu.edu.vn

15 Faculty of Graduate Studies, National Economics University, Hanoi 100000, Vietnam; sshpa.2017@gmail.com

16 Sciences Po Paris, Campus de Dijon, 21000 Dijon, France; thutrang.vuong@sciencespo.fr

17 Vietnam Czech Friendship Hospital, Hai Phong 180000, Vietnam; nguyenquanghungvcfh@gmail.com

18 School of Public Health, University of Alberta, Edmonton, AB T6G 1C9, Canada; mackenzie.moir@gmail.com

19 Graduate School of Medicine, Kyoto University, Kyoto 606-8501, Japan; shimpuku.yoko.5n@kyoto-u.ac.jp

20 Nepal Health Research Council (NHRC), Kathmandu 44600, Nepal; meghdhimal@gmail.com

21 Institute of Occupational Medicine, Social Medicine and Environmental Medicine, Goethe University, Frankfurt am Main 60323, Germany

22 Institute of Chemical Technology, Mumbai 400 019, India; shalu.ghodke@gmail.com

23 London School of Hygiene \& Tropical Medicine, University of London, London WC1E 7HT, UK; surajbpkihs2012@gmail.com

24 Department of Psychological Medicine, National University Hospital, Singapore 119228, Singapore; cyrushosh@gmail.com

25 Department of Psychological Medicine, Yong Loo Lin School of Medicine, National University of Singapore, Singapore 119228, Singapore; hocmroger@yahoo.com.sg

* Correspondence: bach.ipmph@gmail.com; Tel.: +84-98-222-8662

+ These authors contributed equally to this work. 


\begin{abstract}
Child maltreatment remains a major health threat globally that requires the understanding of socioeconomic and cultural contexts to craft effective interventions. However, little is known about research agendas globally and the development of knowledge-producing networks in this field of study. This study aims to explore the bibliometric overview on child maltreatment publications to understand their growth from 1916 to 2018. Data from the Web of Science Core Collection were collected in May 2018. Only research articles and reviews written in the English language were included, with no restrictions by publication date. We analyzed publication years, number of papers, journals, authors, keywords and countries, and presented the countries collaboration and co-occurrence keywords analysis. From 1916 to 2018, 47,090 papers (53.0\% in 2010-2018) were published in 9442 journals. Child Abuse \& Neglect (2576 papers; 5.5\%); Children and Youth Services Review (1130 papers; $2.4 \%$ ) and Pediatrics (793 papers, $1.7 \%$ ) published the most papers. The most common research areas were Psychology (16,049 papers, 34.1\%), Family Studies (8225 papers, 17.5\%), and Social Work (7367 papers, 15.6\%). Among 192 countries with research publications, the most prolific countries were the United States (26,367 papers), England (4676 papers), Canada (3282 papers) and Australia (2664 papers). We identified 17 authors who had more than 60 scientific items. The most cited papers (with at least 600 citations) were published in 29 journals, headed by the Journal of the American Medical Association (JAMA) (7 papers) and the Lancet (5 papers). This overview of global research in child maltreatment indicated an increasing trend in this topic, with the world's leading centers located in the Western countries led by the United States. We called for interdisciplinary research approaches to evaluating and intervening on child maltreatment, with a focus on low-middle income countries (LMICs) settings and specific contexts.
\end{abstract}

Keywords: child maltreatment; scientometrics; child abuse and neglect; global mapping; bibliometric analysis

\title{
1. Introduction
}

The World Health Organization has defined child maltreatment as: "all forms of physical and/or emotional ill-treatment, sexual abuse, neglect or negligent treatment or commercial or other exploitation, resulting in actual or potential harm to the child's health, survival, development or dignity in the context of a relationship of responsibility, trust or power" [1]. This global health issue has existed since ancient civilization [2]. However, finding a full or accurate definition of this social problem is a continuing challenge to researchers, institutions and even governments. Thus, the aims and scope of each paper in this topic are different because of the database [3]. Due to the various definitions, as well as the paper's objectives, we decided to choose the World Health Organization (WHO) definition on child maltreatment.

Approximately 40 million children worldwide are the victims and/or witnesses of child domestic violence each year [1]. Child abuse can be considered a key factor that causes long-life physical and mental health problems for victims and family members. Moreover, an abused child could develop deep and persistent injuries during his/her entire life [4]. Some reports show that the effects of childhood physical abuse can lead to serious emotional and behavioral problems, aggression, violence or depression [5-7]. However, the availability of the data in this research remains a challenge [8]. Finkelhor et al. showed that one of the most cited figures was the probability of a child being sexually abused [9]. This proportion, nevertheless, is different in some scientific meta-analysis. For example, in North America, Gorey et al. found the probability of child abuse to be $12-17 \%$ for girls and 5-8\% for boys in 1997 [10]. Likewise, Finkelhol et al. found the likelihood to be 1 among 9 girls and 1 among 53 boys in 2013 [9]. From an international perspective, Stoltenborgh et al. reported the 
probability of child abuse to be $18.0 \%$ for girls and $7.6 \%$ for boys in 2011 [11]; Pereda et al. reported the proportion of child abuse, particularly child sexual abuse, as $19.2 \%$ and $7.4 \%$ for girls and boys respectively [12]. Although the public awareness of child maltreatment problems has been rising in society in recent times [13], it varies among countries [14,15]. The evolution of child protection began in the late 19th century, yet at different times in each country and beginning at the non-government level. For example, the first child agency, the New York Society for the prevention of Cruelty to Children (NYSPCC), was founded in 1875, followed by the Liverpool and London Society for the Prevention of Cruelty to Children in the UK in 1883 and 1884; in the state of New South Wales in Australia in 1890, and Sweden was the first country introducing a ban on corporal punishment in 1979. By 2016, about 50 countries had prohibited all physical punishment to children. In the United States, 11 States passed Child Access Prevention law to prevent the youth to use or purchase firearms [16]. In India, due to the weakness of the Child Marriage Restraint Law in 1929, a new law banning child marriage was passed in December 2016. In the United States, the International Child Marriage Prevention and Assistance Act was introduced in July 2006, which called for federal efforts to fight child marriage [17]. Legislation about child abuse and protection received the global concern since 1924 with the first International Declaration on the Rights of the Child. Yet this was only the first guidance without legislative authority. Not until 1989, child maltreatment received the official international concern with the United Nations Convention on the Rights of the Child (UNCRC) launching. However, the implication of global legislation met some difficulties [18].

Child maltreatment interventions and policies require substantial empirical evidence with high impacts in different perspectives. One of the primary methods to objectively evaluate the impact of research articles is bibliometric analysis, referring to the method of using measurable information of publications to reveal how the knowledge in the research documents is utilized [19]. Bibliometric analysis of published scientific articles possibly determines the changes of concern for specific topics (child maltreatment in this case) through the growth rate of publications overtime. In addition, the evidence from this analysis can reflect the importance of research topics in national and global contexts via mapping networks of individuals and institutions involving different studies. However, currently, bibliometric studies on the child maltreatment topic are still constrained. Given the needs of evidence about the global trend of child maltreatment research, this study aims to explore the bibliometric overview on child maltreatment publications to understand their growth from 1916 to 2018 . Information from this study will critically contribute to develop the research agenda in this field and allow advancing the theories and models for basic changes in global child maltreatment interventions.

\section{Materials and Methods}

\subsection{Search Strategy}

A cross-sectional study was designed to analyze the bibliography related to child abuse. The Web of Science was selected as the database. Although there were many definitions of child abuse [20], after reviewing some papers, we decided to choose the WHO's conceptual definition of child maltreatment which also helped us to construct the search strategy [1]. To make sure that most of the results would be covered, we also added "child trafficking" and "child grooming" in our search query [21,22]. The search query was built by using the combination of words related to "child maltreatment": child, maltreatment, abuse, violence, sexual, emotional, physical, trafficking, grooming (full strategy in Table S1) via the category "Topic" on the Web of Science. In our study, we have used the following terms interchangeably: child abuse and neglect, child maltreatment, child violence or child abuse. Only two types of research papers were found: research articles and research reviews. Other document types such as books, book chapters or data papers were excluded from this study. There was also a restriction in language as we chose the English items only. However, no publication date was applied to this report. 


\subsection{Data Extraction}

Data, which were downloaded online through the Web of Science, included authors' names, the paper title, the journal name, keywords, institutional affiliations, frequency of citation, subject category, and abstract. Before downloading the data, articles were sorted by the frequency of citation. "Author keywords" and "keywords plus" were both used in this research. Additionally, we also downloaded the citation reports which were created automatically by the Web of Science. All of these data were stored in Microsoft Excel. After that, we filter all the downloaded data by excluding the papers which are: (1) not original articles and reviews; and (2) not about child abuse. A total of 3013 papers were excluded after screening titles and abstracts (Figure 1).

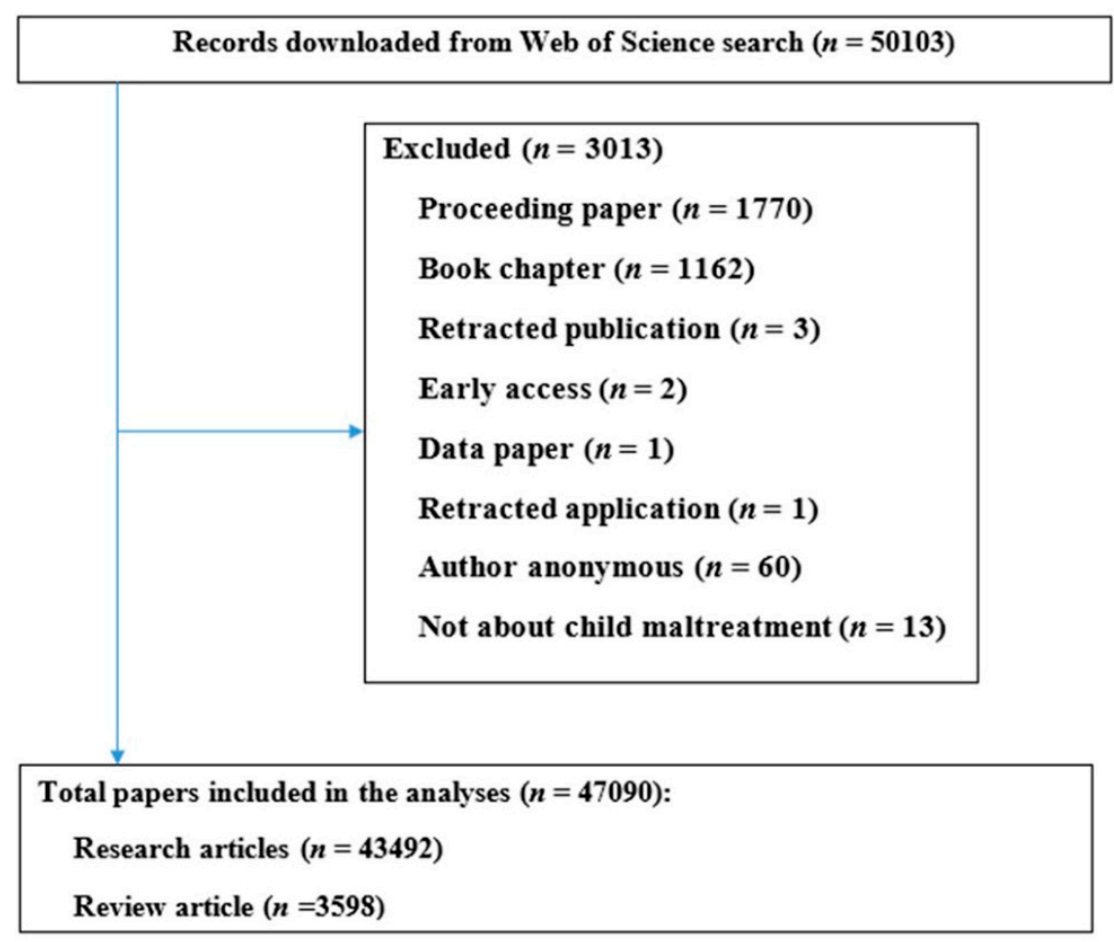

Figure 1. Selection of papers.

\subsection{Data Analysis}

Data were analyzed including: the basic characteristics (number of authors, publication years, main category), keywords (most common keywords and co-occurrence keywords), most prolific authors (more than 60 papers, countries with significant among of publications (more than 75 papers), chief journals, and highly impactful papers (times cited-more than 600 times). A network graph illustrates the connection among countries by applying the specific threshold of 50 papers for each collaboration (Figure 2). To find the most frequent keywords appearing in the keyword plus list, we used Wordle (http: / / www.wordle.net/) as it helped us to create a word cloud online and download the results directly. The larger the words within the cloud, the more often the keywords were repeated. Besides, the author keyword co-occurrence network was also created, which reflects the frequency of the keywords and the proportion of co-words. We used VOSviewer (version 1.6.8, Center for Science and Technology, Leiden University, the Netherlands), free software for creating a co-occurrence network. For countries network, we used Social Networks Visualiser (SocNetV (version 2.4, the Free Software Foundation, Massachusetts, the United States)), a user-friendly and free software tool for Social Network Analysis and Visualization. Data on population were obtained from the World Bank website with the total population of 2016 (https://data.worldbank.org/indicator/SP.POP.TOTL). However, the 2016 population of Wales, Scotland and Northern Ireland was collected from the Office 
for National Statistics Great Britain (https://www.ons.gov.uk/peoplepopulationandcommunity/ populationandmigration/populationestimates).

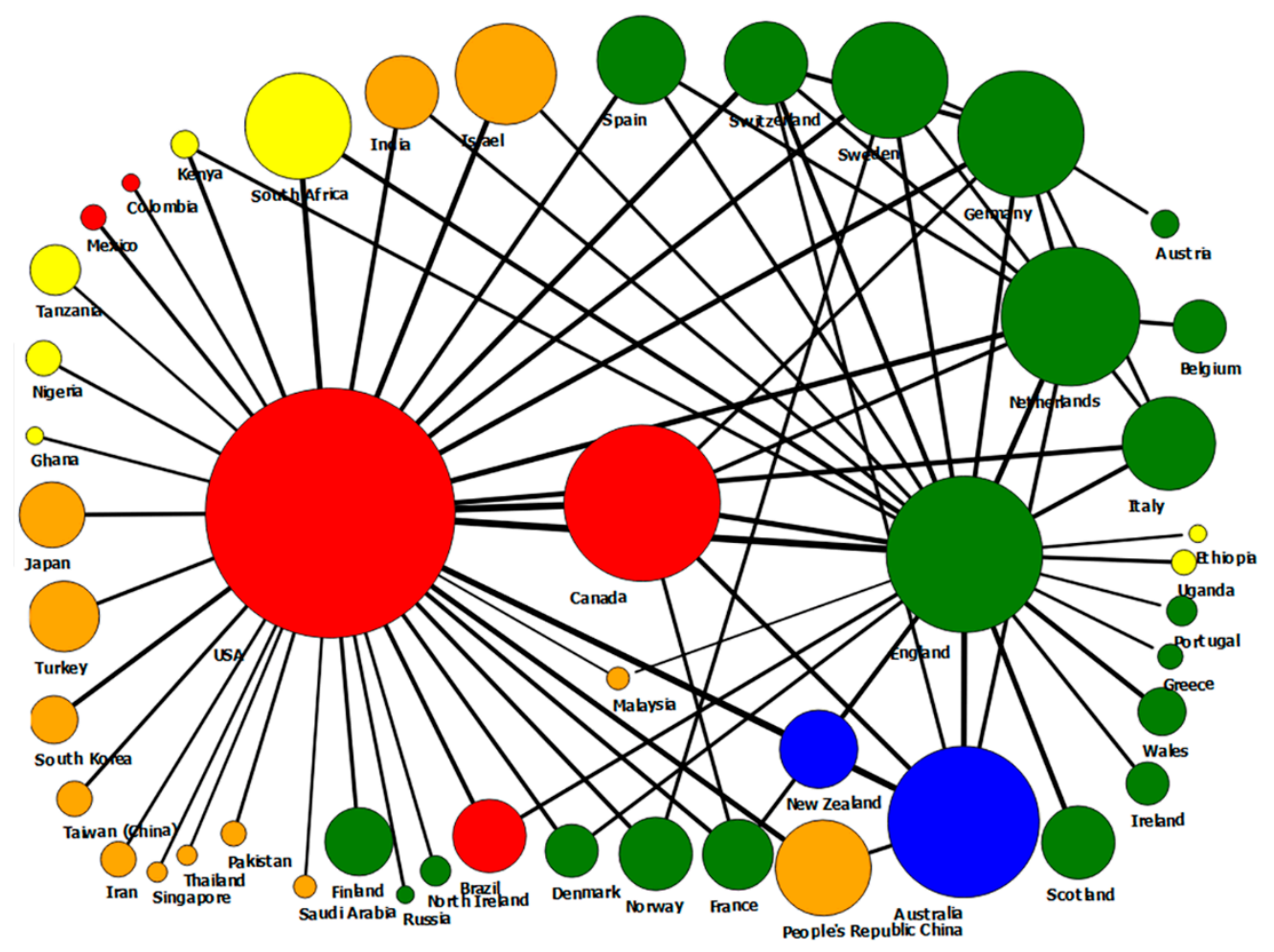

Figure 2. A global network of the most prolific countries (more than 50 papers). Note: America = Red; Europe $=$ Green; Blue $=$ Australia $;$ Asia $=$ Yellow, Africa \& Middle East $=$ Yellow .

\section{Results}

\subsection{Number of Published Items and Publication Trend}

A total of 47,090 research papers (43,492 articles and 3598 reviews) were included in the analysis, while 3013 documents that did not match eligible criteria were excluded (Figure 1).

Table 1 shows the characteristics of the papers. 47,090 papers were published by 9442 journals. $6478(68.6 \%)$ journals published one paper, 808 journals published two, $393(4.2 \%)$ journals published three and $1736(18.7 \%)$ journals published four or more. Two journals that published the most papers were Child Abuse and Neglect $(n=2576 ; 5.5 \%)$ and Children and Youth Services Review $(n=1130$; $2.4 \%)$, followed by Pediatrics ( $n=793 ; 1.7 \%)$, Journal of Interpersonal Violence $(n=661 ; 1.4 \%)$ and Journals of Family Violence $(n=518 ; 1.1 \%)$. Most of the papers $(82.7 \%)$ were sorted into one $(n=23,869$; $50.7 \%)$ or two $(n=15,077 ; 32 \%)$ subject categories of the journals. Psychology $(n=16,049 ; 34.1 \%)$ and family studies $(n=8225 ; 17.5 \%)$ were two main subject categories.

Table 2 displayed in detail the most productive subject categories, with more than 500 papers, as well as the journals in which they were published. Child Abuse \& Neglect was the leading journal with regards to the number of papers in these subjects: Psychology, Family Studies, and Social work. Among all topics, Child maltreatment was the one which attracted the huge concern of the community that could be clearly seen from the diversity of the subject categories, such as psychology, family studies, pediatric or government law, legal medicine or criminology penology. 
Table 1. Characteristics of selected articles.

\begin{tabular}{|c|c|c|c|}
\hline Characteristic & Category & Number & Percent \\
\hline Total number of papers & & 47,090 & 100.0 \\
\hline \multicolumn{4}{|l|}{ Year of publication } \\
\hline & 1916-1979 & 500 & 1.1 \\
\hline & 1980-1989 & 1113 & 2.4 \\
\hline & 1990-1999 & 7066 & 15.0 \\
\hline & 2000-2009 & 13,464 & 28.6 \\
\hline & $2010-2018$ & 24,947 & 53.0 \\
\hline \multicolumn{4}{|l|}{ Number of authors } \\
\hline & 1 & 8398 & 17.8 \\
\hline & $2-3$ & 18,520 & 39.3 \\
\hline & $4-6$ & 14,787 & 31.4 \\
\hline & $7-10$ & 4265 & 9.1 \\
\hline & $>10$ & 1120 & 2.4 \\
\hline \multicolumn{4}{|l|}{ Number of subject categories } \\
\hline & 1 & 23,869 & 50.7 \\
\hline & 2 & 15,077 & 32.0 \\
\hline & 3 & 7484 & 15.9 \\
\hline & 4 & 563 & 1.2 \\
\hline & $>5$ & 97 & 0.2 \\
\hline \multicolumn{4}{|l|}{ Main subject categories } \\
\hline & Psychology & 16,049 & 34.1 \\
\hline & Family studies & 8225 & 17.5 \\
\hline & Social work & 7367 & 15.6 \\
\hline & Psychiatry & 6365 & 13.5 \\
\hline & Pediatrics & 4938 & 10.5 \\
\hline & Others & 4146 & 8.8 \\
\hline \multicolumn{4}{|c|}{ Country of the first author (top 10) } \\
\hline & United States & 26,371 & 56.0 \\
\hline & England & 4675 & 9.9 \\
\hline & Canada & 3282 & 7.0 \\
\hline & Australia & 2664 & 5.7 \\
\hline & Netherlands & 1244 & 2.6 \\
\hline & Germany & 1188 & 2.5 \\
\hline & Sweden & 1002 & 2.1 \\
\hline & South Africa & 911 & 1.9 \\
\hline & Israel & 860 & 1.8 \\
\hline & The People's Republic of China & 755 & 1.6 \\
\hline
\end{tabular}


Table 2. Journal subject categories and the journals which included those subject categories.

\begin{tabular}{|c|c|c|c|c|c|}
\hline Journal Subject Category & $\begin{array}{l}\text { Total } \\
\text { Papers }\end{array}$ & Journal Name & $\begin{array}{l}\text { Total } \\
\text { Papers }\end{array}$ & Journal Name & $\begin{array}{l}\text { Total } \\
\text { Papers }\end{array}$ \\
\hline \multirow[t]{3}{*}{ Psychology } & 16,049 & Child Abuse \& Neglect & 2576 & $\begin{array}{l}\text { Journal of The American Academy of Child } \\
\text { And Adolescent Psychiatry }\end{array}$ & 492 \\
\hline & & Journal of Interpersonal Violence & 661 & Journal of Child Sexual Abuse & 377 \\
\hline & & Journal of Family Violence & 518 & Development and Psychopathology & 327 \\
\hline \multirow[t]{2}{*}{ Family studies } & 8225 & Child Abuse \& Neglect & 2576 & Journal of Family Violence & 518 \\
\hline & & Journal of Interpersonal Violence & 661 & Child Maltreatment & 362 \\
\hline \multirow[t]{3}{*}{ Social work } & 7367 & Child Abuse \& Neglect & 2576 & Child Welfare & 355 \\
\hline & & Children and Youth Services Review & 1130 & American Journal of Orthopsychiatry & 304 \\
\hline & & Child Maltreatment & 362 & British Journal of Social Work & 255 \\
\hline \multirow[t]{3}{*}{ Psychiatry } & 6365 & $\begin{array}{l}\text { Journal of The American Academy of Child } \\
\text { and Adolescent Psychiatry }\end{array}$ & 492 & Journal of Traumatic Stress & 190 \\
\hline & & American Journal of Orthopsychiatry & 304 & Journal of Child Psychology and Psychiatry & 164 \\
\hline & & Journal of Child and Family Studies & 238 & $\begin{array}{l}\text { Child and Adolescent Psychiatric Clinics of } \\
\text { North America }\end{array}$ & 151 \\
\hline \multirow[t]{3}{*}{ Pediatric } & 4938 & Pediatrics & 793 & Archives of Disease in Childhood & 211 \\
\hline & & $\begin{array}{l}\text { Journal of The American Academy of Child } \\
\text { and Adolescent Psychiatry }\end{array}$ & 492 & Pediatric Emergency Care & 198 \\
\hline & & Journal of Adolescent Health & 246 & Archives of Pediatrics Adolescent Medicine & 171 \\
\hline \multirow[t]{3}{*}{$\begin{array}{l}\text { Public environmental } \\
\text { occupational health }\end{array}$} & 4937 & Journal of Adolescent Health & 246 & American Journal of Public Health & 137 \\
\hline & & BMC Public Health & 242 & Journal of Community Psychology & 136 \\
\hline & & Social Science Medicine & 200 & Accident Analysis and Prevention & 121 \\
\hline Criminology penology & 2642 & Journal of Interpersonal Violence & 661 & $\begin{array}{l}\text { International Journal of Offender Therapy } \\
\text { and Comparative Criminology }\end{array}$ & 117 \\
\hline
\end{tabular}


Table 2. Cont

\begin{tabular}{|c|c|c|c|c|c|}
\hline Journal Subject Category & $\begin{array}{l}\text { Total } \\
\text { Papers }\end{array}$ & Journal Name & $\begin{array}{l}\text { Total } \\
\text { Papers }\end{array}$ & Journal Name & $\begin{array}{l}\text { Total } \\
\text { Papers }\end{array}$ \\
\hline & & Aggression and Violent Behavior & 242 & Trauma Violence Abuse & 113 \\
\hline & & Violence and Victims & 126 & Criminal Justice and Behavior & 112 \\
\hline \multirow[t]{2}{*}{ General \& internal medicine } & 2149 & American Journal of Preventive Medicine & 121 & $\begin{array}{l}\text { JAMA Journal of The American Medical } \\
\text { Association }\end{array}$ & 78 \\
\hline & & Lancet & 116 & BMJ Open & 67 \\
\hline \multirow[t]{3}{*}{ Neurosciences neurology } & 1822 & Journal of Affective Disorders & 113 & Psychoneuroendocrinology & 47 \\
\hline & & Journal of Nervous and Mental Disease & 94 & Neurotoxic Ology and Teratology & 34 \\
\hline & & Biological Psychiatry & 82 & Childs Nervous System & 33 \\
\hline \multirow[t]{2}{*}{ Substance abuse } & 1589 & Drug and Alcohol Dependence & 134 & Addiction & 102 \\
\hline & & Addictive Behaviors & 117 & $\begin{array}{l}\text { Journal of Child \& Adolescent Substance } \\
\text { Abuse }\end{array}$ & 99 \\
\hline \multirow[t]{3}{*}{ Government law } & 1475 & Behavioral Sciences \& The Law & 107 & Law and Human Behavior & 76 \\
\hline & & Psychology Crime Law & 84 & Psychology Public Policy and Law & 76 \\
\hline & & Juvenile and Family Court Journal & 77 & Psychiatry Psychology and Law & 71 \\
\hline \multirow[t]{3}{*}{ Social sciences other topics } & 1217 & Accident Analysis and Prevention & 121 & $\begin{array}{l}\text { Childhood a Global Journal of Child } \\
\text { Research }\end{array}$ & 62 \\
\hline & & Archives of Sexual Behavior & 82 & Child Indicators Research & 48 \\
\hline & & Future of Children & 63 & Evaluation and Program Planning & 44 \\
\hline \multirow[t]{3}{*}{$\begin{array}{l}\text { Education \& educational } \\
\text { research }\end{array}$} & 1215 & Journal of School Health & 90 & Research in Developmental Disabilities & 34 \\
\hline & & $\begin{array}{l}\text { Journal of Emotional and Behavioral } \\
\text { Disorders }\end{array}$ & 46 & Journal of Intellectual Disability Research & 29 \\
\hline & & Journal of Drug Education & 41 & Health Education Research & 24 \\
\hline
\end{tabular}


Table 2. Cont.

\begin{tabular}{|c|c|c|c|c|c|}
\hline Journal Subject Category & $\begin{array}{l}\text { Total } \\
\text { Papers }\end{array}$ & Journal Name & $\begin{array}{l}\text { Total } \\
\text { Papers }\end{array}$ & Journal Name & $\begin{array}{l}\text { Total } \\
\text { Papers }\end{array}$ \\
\hline \multirow[t]{3}{*}{ Health care sciences services } & 1004 & Journal of School Health & 90 & Future of Children & 63 \\
\hline & & Psychiatric Services & 76 & Community Mental Health Journal & 48 \\
\hline & & Psychology Public Policy and Law & 76 & $\begin{array}{l}\text { AIDS Care Psychological and Socio-Medical } \\
\text { Aspects of AIDS/HIV }\end{array}$ & 44 \\
\hline \multirow[t]{3}{*}{ Environmental sciences ecology } & 974 & $\begin{array}{l}\text { International Journal of Environmental } \\
\text { Research and Public Health }\end{array}$ & 105 & Environmental Research & 85 \\
\hline & & Science of the Total Environment & 96 & Atmospheric Environment & 80 \\
\hline & & Environmental Health Perspectives & 91 & Environmental Health & 36 \\
\hline \multirow[t]{3}{*}{ Nursing } & 863 & Journal of Advanced Nursing & 53 & Journal of Pediatric Health Care & 36 \\
\hline & & Public Health Nursing & 52 & Nursing Clinics of North America & 35 \\
\hline & & Journal of Clinical Nursing & 45 & Revista Latino Americana de Enfermagem & 29 \\
\hline \multirow[t]{2}{*}{ Surgery } & 704 & $\begin{array}{l}\text { Journal of Trauma: Injury Infection and } \\
\text { Critical Care }\end{array}$ & 60 & Journal of Pediatric Surgery & 37 \\
\hline & & Burns & 40 & Pediatric Surgery International & 28 \\
\hline \multirow[t]{3}{*}{ Sociology } & 648 & Journal of Marriage and Family & 56 & Deviant Behavior & 29 \\
\hline & & Youth Society & 34 & Journal of Health And Social Behavior & 18 \\
\hline & & Journal of Marriage and The Family & 31 & Social Forces & 18 \\
\hline \multirow[t]{3}{*}{ Biomedical social sciences } & 594 & Social Science Medicine & 200 & AIDS and Behavior & 29 \\
\hline & & $\begin{array}{l}\text { AIDS Care Psychological and Socio-Medical } \\
\text { Aspects of AIDS/HIV }\end{array}$ & 44 & Culture Health Sexuality & 21 \\
\hline & & Qualitative Health Research & 34 & Journal of Biosocial Science & 20 \\
\hline Legal medicine & 561 & Forensic Science International & 120 & Journal of Forensic and Legal Medicine & 71 \\
\hline
\end{tabular}


Table 2. Cont

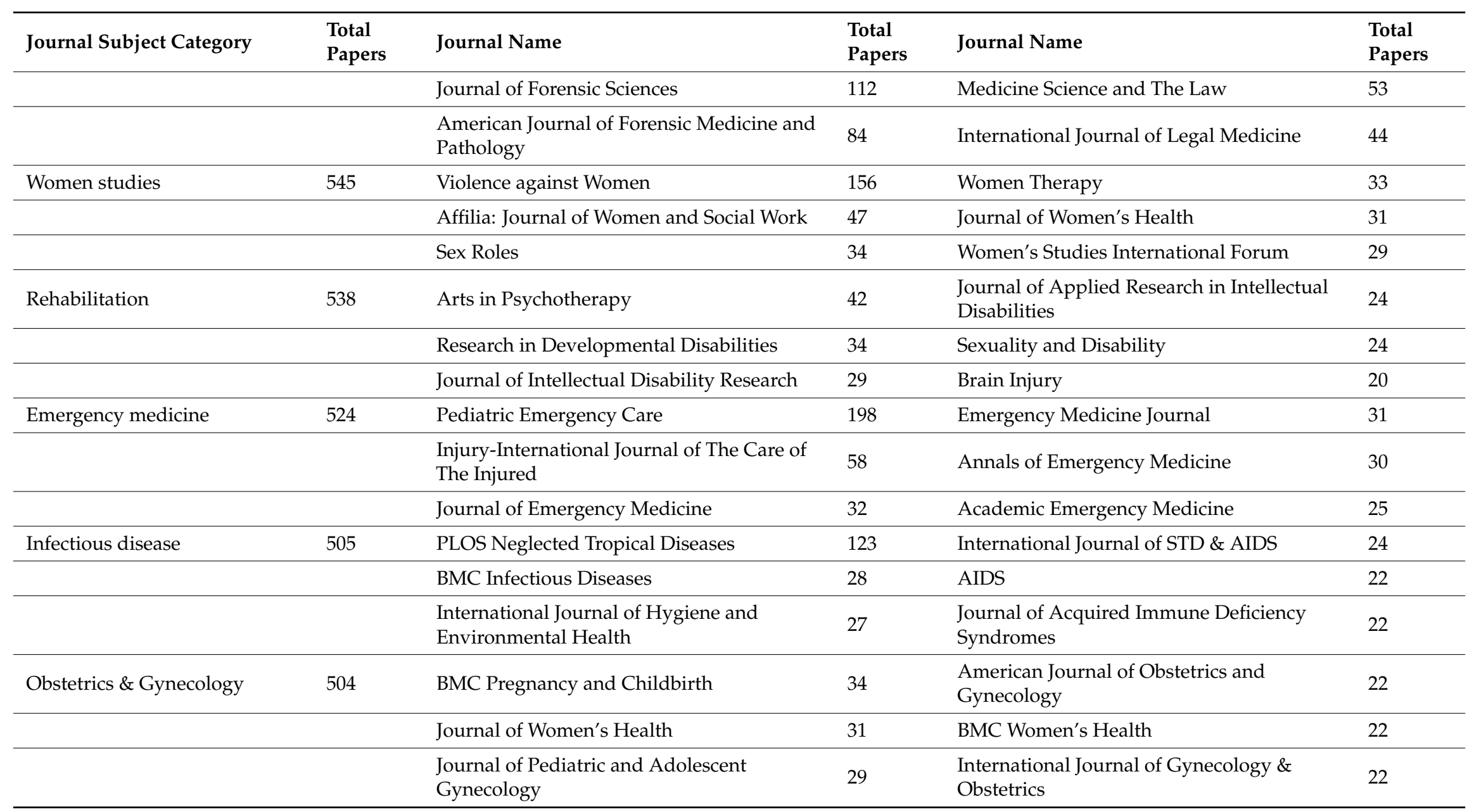




\subsection{Author and Countries}

As can be seen in Table 1 , nearly $40 \%(n=18,526)$ of the papers were the work of 2 or 3 authors; the number of papers with 4 or 6 authors was 14,789 $(31.4 \%)$, and only 11.5\% $(n=665)$ items were written by seven or more authors. About $80.2 \%(n=37,769)$ of total papers belonged to the first authors from North America and Europe. The first authors of the United States contributed 26,377 (56\%) papers.

The results in Table 3 indicate the most productive authors with more than 60 papers during the time of the study. The American authors are amongst the most prolific, with ten authors who contributed much to this research area. Dante Cicchetti from the University of Minnesota, United States led the number of published papers (159 publications), as well as the number of papers in collaboration. However, Bert Brunekreef (Wageningen University \& Research, Netherlands) was the author who received the most citations per paper.

Table 4 illustrates the productivity ranking of 192 countries involved in the sample of papers. In this list, the top five countries were from North America, Europe, and Australia. It appears that the United States was the knowledge hub of the world in this field. They ranked top in all indices: total papers (26,371 papers, $56 \%$ ), total collaborations (9487 organizations), total citations (nearly eight hundred thousand), and countries in collaboration (169 countries). They were also the main collaborators of 37 countries (74\%) in this list. England was in second place with 4676 papers $(9.9 \%)$ and was the main collaborator of the countries in the United Kingdom and five other countries in Europe and Africa. The People's Republic China was the only Asian country on the list of 10 leading countries in the number of total papers. However, they produced only 0.55 articles per one million inhabitants, which made them rank last in the list of papers per million inhabitants. New Zealand was ranked first in this list with 129.55 papers per million inhabitants.

Figure 2 displays the global network between 18 countries (with at least 50 papers in co-authorship), in which the connectivity of those countries and the position of each country in the network can be easily discovered. The size of nodes shows the proportional contribution to the number of papers and the thickness of lines indicates the percentage of the number of collaboration.

Figure 3 reveals the most common keywords which appeared more than 700 times in the literature (automatically counted by the Wordle); "children" was the most common word, appearing in 10,975 papers (23\%), followed by "violence", "abuse", "behavior" and "adolescents" which occurred in 8931 papers (19\%), 5890 papers (13\%), 4493 papers (10\%), and 4013 papers (9\%) respectively.

Figure 4 points out the keyword co-occurrence which is a measure of the probability that a particular word appears on the Web of Science search results. As can be seen in the figure, "child abuse" and "children" were two common words coming out the most amongst authors' keywords. The thickness of the lines indicates the strength of one given keyword relative to the others, such as, the association of "child abuse" and "children" with "mental health", "parenting", "violence" or "depression"; the association of "prevention" with "child maltreatment", "child sexual abuse", "child abuse" or "intervention". Looking at Figure 4, we identified the main groups, including: (1) research subjects (children, adolescents, child and women); (2) types of maltreatment (child abuse, sexual abuse, physical abuse, neglect, maltreatment, violence, bullying); (3) health outcomes (post-traumatic stress disorder (PTSD), stress, depression, pregnancy, mental health, and trauma); (4) risk factors (substance abuse, substance use, and alcohol); and (5) child protection (intervention, prevention, and treatment). 
Table 3. Most prolific authors.

\begin{tabular}{|c|c|c|c|c|c|c|c|c|}
\hline No & Author & Affiliation and Country & $\begin{array}{c}\text { Total } \\
\text { Papers }\end{array}$ & $\begin{array}{l}\text { Total } \\
\text { Citations }\end{array}$ & $\begin{array}{l}\text { Citations } \\
\text { per Paper }\end{array}$ & $\begin{array}{l}\text { Papers in } \\
\text { Collaboration }\end{array}$ & $\begin{array}{c}\text { Total } \\
\text { Signatures }\end{array}$ & $\begin{array}{l}\text { Collaboration Index } \\
\text { (Signatures per Paper) }\end{array}$ \\
\hline 1 & Dante Cicchetti & University of Minnesota, United States & 159 & 11,237 & 70.7 & 151 & 566 & 3.6 \\
\hline 2 & David Finkelhor & University of New Hampshire, United States & 116 & 11,602 & 100.0 & 107 & 377 & 3.3 \\
\hline 3 & Howard Dubowitz & University of Maryland School of Medicine, United States & 96 & 3166 & 33.0 & 87 & 531 & 5.5 \\
\hline 4 & Michael E. Lamb & University of Cambridge, England & 96 & 3988 & 41.5 & 91 & 366 & 3.8 \\
\hline 5 & David M. Fergusson & University of Otago, New Zealand & 87 & 8781 & 100.9 & 87 & 260 & 3.0 \\
\hline 6 & Joel S Milner & Northern Illinois University, United States & 83 & 2061 & 24.8 & 76 & 335 & 4.0 \\
\hline 7 & John L. Horwood & Univ Otago Christchurch, New Zealand & 77 & 6919 & 89.9 & 77 & 240 & 3.1 \\
\hline 8 & Cathy Spatz Widom & CUNY John Jay Coll Criminal Justice, United States & 73 & 7354 & 100.7 & 65 & 185 & 2.5 \\
\hline 9 & Gail S. Goodman & University of California Davis, United States & 71 & 2627 & 37.0 & 70 & 384 & 5.4 \\
\hline 10 & Martine B. Powell & Deakin University, Australia & 70 & 654 & 9.3 & 69 & 212 & 3.0 \\
\hline 11 & Fred A. Rogosch & University of Rochester, United States & 68 & 3627 & 53.3 & 68 & 246 & 3.6 \\
\hline 12 & Jürg Utzinger & $\begin{array}{l}\text { Swiss Tropical \& Public Health Institute, University of Basel, } \\
\text { Switzerland }\end{array}$ & 68 & 2231 & 32.8 & 68 & 694 & 10.2 \\
\hline 13 & Bert Brunekreef & Wageningen University \& Research, Netherlands & 65 & 6761 & 104.0 & 65 & 1528 & 23.5 \\
\hline 14 & Kenneth A. Dodge & Duke University, United States & 65 & 4891 & 75.2 & 61 & 451 & 6.9 \\
\hline 15 & Harriet L. MacMillan & McMaster University, Canada & 65 & 2732 & 42.0 & 63 & 345 & 5.3 \\
\hline 16 & Desmond K. Runyan & University of North Carolina, United States & 64 & 2548 & 39.8 & 64 & 401 & 6.3 \\
\hline 17 & Penelope K. Trickett & University of Southern California, United States & 61 & 2827 & 46.3 & 61 & 237 & 3.9 \\
\hline
\end{tabular}

Table 4. Most prolific countries and the collaborations.

\begin{tabular}{|c|c|c|c|c|c|c|c|c|}
\hline Country & Total Papers & $\begin{array}{l}\text { Papers per Million } \\
\text { Inhabitants }\end{array}$ & $\begin{array}{c}\text { Total } \\
\text { Collaborations }\end{array}$ & $\begin{array}{c}\text { Total } \\
\text { Citations }\end{array}$ & $\begin{array}{l}\text { Citations } \\
\text { per Paper }\end{array}$ & $\begin{array}{c}\text { Papers in } \\
\text { Collaboration } \\
\text { (Distinct Country) }\end{array}$ & $\begin{array}{c}\text { Distinct } \\
\text { Countries of } \\
\text { Collaboration }\end{array}$ & $\begin{array}{l}\text { Main Collaborator } \\
\text { (and Number of } \\
\text { Collaborations) }\end{array}$ \\
\hline USA & 26,377 & 81.63 & 9487 & 784,603 & 29.75 & 3784 & 169 & Canada (683) \\
\hline England & 4675 & 84.61 & 3990 & 124,144 & 26.55 & 2051 & 143 & USA (682) \\
\hline Australia & 2664 & 110.03 & 2506 & 50,977 & 19.14 & 893 & 130 & USA (321) \\
\hline Netherlands & 1244 & 73.05 & 2276 & 37,658 & 30.27 & 607 & 134 & USA (189) \\
\hline Germany & 1188 & 14.40 & 2229 & 30,196 & 25.41 & 576 & 130 & USA (226) \\
\hline Sweden & 1002 & 100.98 & 1761 & 25,502 & 25.47 & 434 & 127 & USA (147) \\
\hline South Africa & 910 & 22.64 & 1597 & 20,626 & 22.64 & 432 & 125 & USA (212) \\
\hline
\end{tabular}


Table 4. Cont.

\begin{tabular}{|c|c|c|c|c|c|c|c|c|}
\hline Country & Total Papers & $\begin{array}{l}\text { Papers per Million } \\
\text { Inhabitants }\end{array}$ & $\begin{array}{c}\text { Total } \\
\text { Collaborations }\end{array}$ & $\begin{array}{c}\text { Total } \\
\text { Citations }\end{array}$ & $\begin{array}{l}\text { Citations } \\
\text { per Paper }\end{array}$ & $\begin{array}{c}\text { Papers in } \\
\text { Collaboration } \\
\text { (Distinct Country) }\end{array}$ & $\begin{array}{c}\text { Distinct } \\
\text { Countries of } \\
\text { Collaboration }\end{array}$ & $\begin{array}{l}\text { Main Collaborator } \\
\text { (and Number of } \\
\text { Collaborations) }\end{array}$ \\
\hline The People's Republic of China & 755 & 0.55 & 1839 & 17,299 & 22.91 & 355 & 123 & USA (194) \\
\hline Italy & 738 & 12.17 & 2117 & 20,766 & 28.14 & 347 & 132 & USA (143) \\
\hline Spain & 695 & 14.95 & 1849 & 15,148 & 21.80 & 411 & 128 & USA (94) \\
\hline Switzerland & 655 & 78.59 & 1959 & 32,891 & 49.99 & 495 & 134 & USA (200) \\
\hline New Zealand & 608 & 129.55 & 1352 & 32,584 & 53.59 & 230 & 115 & USA (88) \\
\hline Brazil & 576 & 2.77 & 1578 & 8440 & 14.65 & 211 & 121 & USA (93) \\
\hline India & 571 & 0.43 & 1723 & 11,357 & 19.89 & 170 & 119 & USA (101) \\
\hline Norway & 550 & 105.04 & 1474 & 10,126 & 18.41 & 225 & 120 & USA (86) \\
\hline Scotland & 548 & 101.58 & 1475 & 15,431 & 28.11 & 264 & 125 & England (165) \\
\hline France & 528 & 7.89 & 1393 & 16,876 & 31.96 & 265 & 129 & USA (90) \\
\hline Turkey & 512 & 6.44 & 1275 & 5715 & 11.16 & 85 & 112 & USA (54) \\
\hline Finland & 456 & 82.98 & 1332 & 12,090 & 26.51 & 164 & 120 & USA (59) \\
\hline Japan & 437 & 3.44 & 1576 & 10,483 & 23.99 & 127 & 122 & USA (71) \\
\hline Denmark & 367 & 64.07 & 1443 & 11,753 & 32.02 & 197 & 125 & USA (71) \\
\hline Belgium & 352 & 31.04 & 1338 & 7884 & 22.40 & 208 & 118 & Netherlands (74) \\
\hline South Korea & 331 & 6.46 & 1298 & 4610 & 13.93 & 158 & 116 & USA (123) \\
\hline Wales & 330 & 106.00 & 1099 & 8128 & 24.63 & 187 & 106 & England (145) \\
\hline Ireland & 280 & 58.95 & 1183 & 9099 & 32.50 & 135 & 107 & England (54) \\
\hline Taiwan (China) & 226 & 9.60 & 1170 & 4017 & 17.77 & 81 & 116 & USA (54) \\
\hline Nigeria & 220 & 1.18 & 1278 & 3989 & 18.13 & 82 & 120 & USA (44) \\
\hline Iran & 215 & 2.68 & 1155 & 2734 & 12.72 & 70 & 113 & USA (35) \\
\hline Northern Ireland & 188 & 100.96 & 226 & 2500 & 13.30 & 89 & 41 & USA (35) \\
\hline Portugal & 184 & 17.82 & 1255 & 2837 & 15.42 & 83 & 122 & England (27) \\
\hline Austria & 175 & 20.04 & 1205 & 5847 & 33.41 & 103 & 105 & Germany (43) \\
\hline Kenya & 174 & 3.59 & 1285 & 4498 & 25.85 & 149 & 119 & USA (96) \\
\hline Greece & 154 & 14.30 & 1243 & 4155 & 26.98 & 68 & 120 & England (32) \\
\hline Mexico & 150 & 1.18 & 1271 & 7784 & 51.89 & 86 & 118 & USA (69) \\
\hline Uganda & 150 & 3.62 & 1140 & 6271 & 41.81 & 137 & 114 & England (65) \\
\hline Pakistan & 139 & 0.72 & 1205 & 3959 & 28.48 & 81 & 113 & USA (40) \\
\hline Poland & 134 & 3.53 & 1007 & 1996 & 14.90 & 41 & 105 & England (14) \\
\hline Malaysia & 123 & 3.94 & 1128 & 2260 & 18.37 & 60 & 115 & Australia (16) \\
\hline Saudi Arabia & 122 & 3.78 & 1161 & 5737 & 47.02 & 57 & 116 & USA (25) \\
\hline Singapore & 111 & 19.80 & 1156 & 6438 & 58.00 & 65 & 116 & USA (30) \\
\hline Thailand & 103 & 1.50 & 660 & 1845 & 17.91 & 72 & 96 & USA (27) \\
\hline Egypt & 102 & 1.07 & 1096 & 2398 & 23.51 & 47 & 114 & Saudi Arabia (18) \\
\hline Tanzania & 95 & 1.71 & 1116 & 3805 & 40.05 & 86 & 120 & USA (31) \\
\hline Ethiopia & 94 & 0.92 & 1098 & 3296 & 35.06 & 59 & 114 & England (30) \\
\hline Columbia & 92 & 1.89 & 1174 & 3296 & 35.06 & 68 & 122 & USA (46) \\
\hline Croatia & 89 & 21.32 & 165 & 751 & 8.44 & 24 & 40 & USA (8) \\
\hline Russia & 83 & 0.58 & 1174 & 5585 & 67.29 & 53 & 118 & USA (40) \\
\hline Ghana & 78 & 2.77 & 1194 & 5787 & 74.19 & 66 & 114 & USA (34) \\
\hline
\end{tabular}




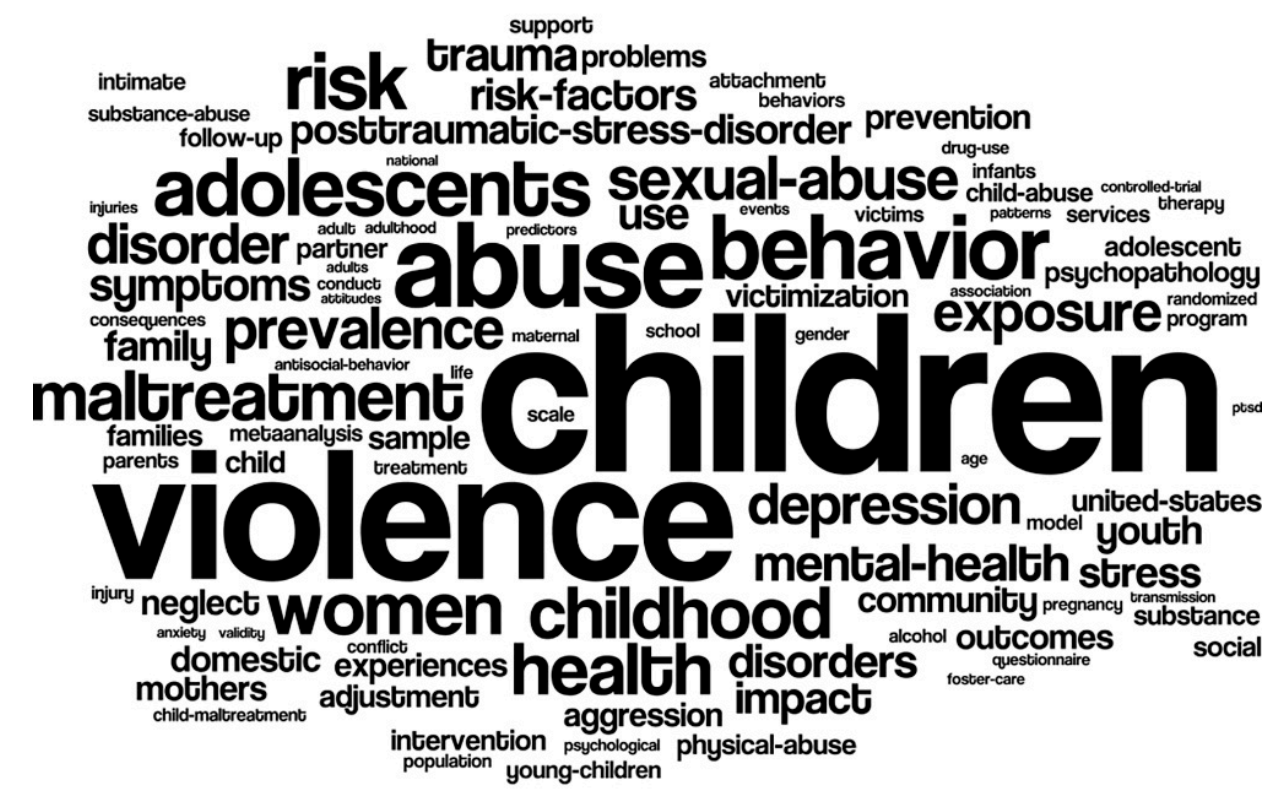

Figure 3. The most frequent keywords.

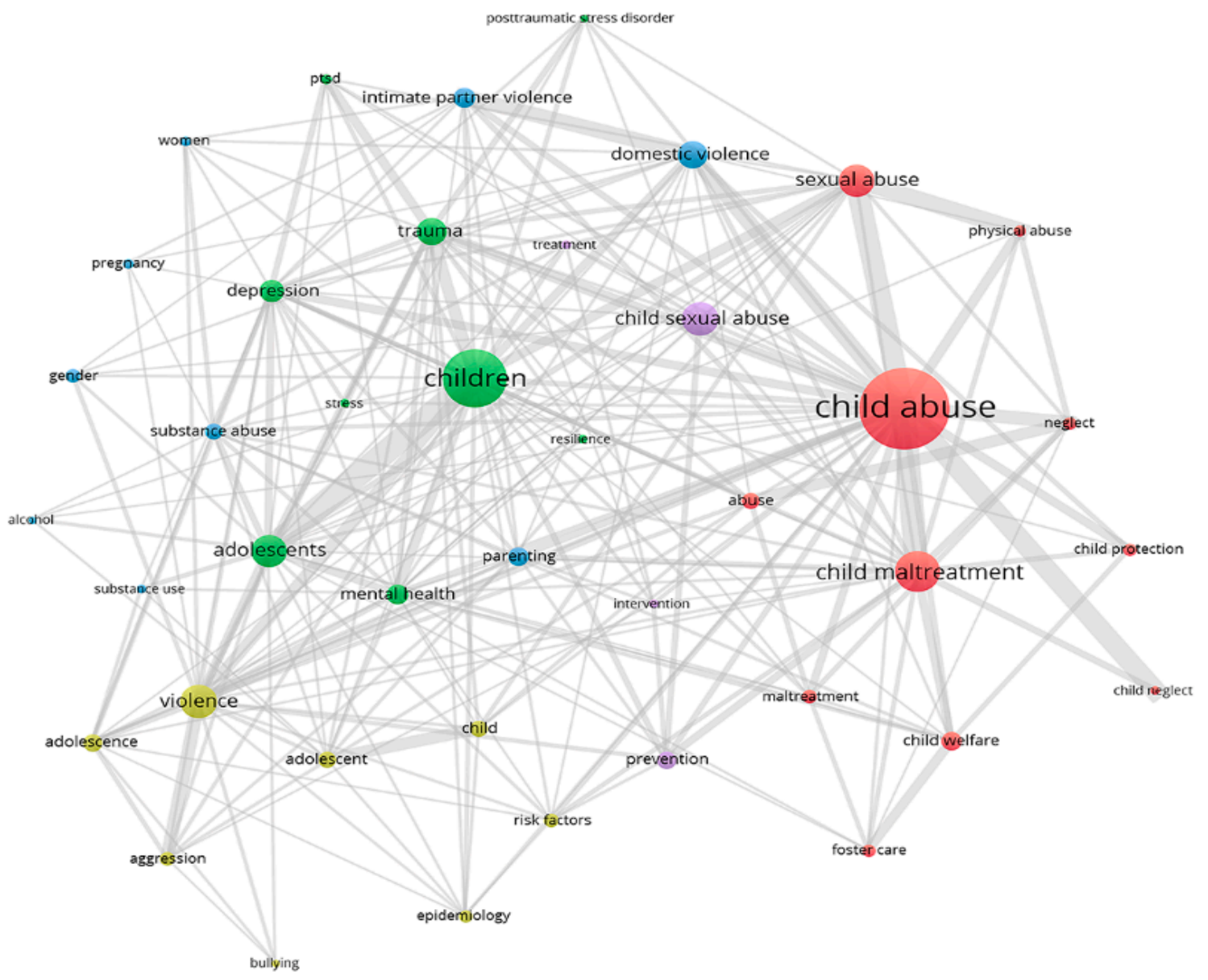

Figure 4. Co-occurrence of author's keyword. Note: the colors of the nodes were automatically assigned by the software; the nodes' size was scaled to the keywords' occurrences; the thickness of the lines was automatically drawn by the software based on the strength of two keywords. 


\subsection{Most Cited Papers}

The list of papers with the highest number of citations can be found in Table 5 . In total, all papers included in this research together received about 1.1 million citations, of which 2022 papers have more than 100 citations. Those most highly cited papers (48 papers in the list) were published in 29 journals, headed by JAMA Journal of the American Medical Association with seven papers, followed by the Lancet, containing five papers. This list also shows the comprehensive review of research on the following topics: the effect of neighborhood or family and community on the children (paper number 7 and paper number 47 respectively in Table 5); the survey and research about child abuse (paper number 42, number 46 and number 48 in Table 5); the effect of child abuse (paper number 6, number 10, number 14, number 15, number 18, number 28, number 29, number 34 and number 39 in Table 5); the investigation in bullying and the role of schoolboys and schoolgirls within the group process in a Finnish school (paper number 35 in Table 5); and the negative outcomes of bullying among the US youth, in paper number 5 , as well as suggestions regarding preventing interventions. 
Table 5. Most cited papers.

\begin{tabular}{|c|c|c|c|}
\hline Rank & Paper & Total Citation & Citations/Year \\
\hline 1 & $\begin{array}{l}\text { Felitti VJ, Anda RF, Nordenberg D, Williamson DF, Spitz AM, Edwards V, Koss MP, Marks JS. Relationship of childhood } \\
\text { abuse and household dysfunction to many of the leading causes of death in adults-The adverse childhood experiences } \\
\text { (ACE) study. American Journals of Preventive Medicine. 1998;14:245-258 }\end{array}$ & 3356 & 167.8 \\
\hline 2 & $\begin{array}{l}\text { Lozano R, et al. Global and regional mortality from } 235 \text { causes of death for } 20 \text { age groups in } 1990 \text { and 2010: a systematic } \\
\text { analysis for the Global Burden of Disease Study 2010. Lancet. 2012;380:2095-2128 }\end{array}$ & 3307 & 551.2 \\
\hline 3 & $\begin{array}{l}\text { Caspi A, McClay J, Moffitt TE, Mill J, Martin J, Craig IW, Taylor A, Poulton R. Role of genotype in the cycle of violence in } \\
\text { maltreated children. Science. 2002;297:851-854 }\end{array}$ & 2366 & 147.9 \\
\hline 4 & $\begin{array}{l}\text { Resnick MD, Bearman PS, Blum RW, Bauman, KE, Harris KM, Jones J, Tabor J, Beuhring T, Sieving RE, Shew M, Ireland M, } \\
\text { Bearinger LH, Udry JR. Protecting adolescents from harm-Findings from the National Longitudinal Study on Adolescent } \\
\text { Health. JAMA Journal of the American Medical Association. 1997;278:823-832 }\end{array}$ & 2335 & 111.2 \\
\hline 5 & $\begin{array}{l}\text { Nansel TR, Overpeck M, Pilla RS, Ruan WJ, Simons-Morton B, Scheidt P. Bullying behaviors among US youth-Prevalence } \\
\text { and association with psychosocial adjustment. JAMA Journal of the American Medical Association. 2001;285:2094-2100 }\end{array}$ & 1601 & 94.2 \\
\hline 6 & Browne A; Finkelhor D. Impact of child sexual abuse—a review of the research. Psychological Bulletin. 1986;99:66-77 & 1464 & 45.8 \\
\hline 7 & $\begin{array}{l}\text { Leventhal T, Brooks-Gunn J. The neighborhoods they live in: The effects of neighborhood residence on child and } \\
\text { adolescent outcomes. Psychological Bulletin. 2000;126:309-337 }\end{array}$ & 1461 & 81.2 \\
\hline 8 & $\begin{array}{l}\text { Heim C; Nemeroff CB. The role of childhood trauma in the neurobiology of mood and anxiety disorders: Preclinical and } \\
\text { clinical studies. Biological Psychiatry. 2001;49:1023-1039 }\end{array}$ & 1408 & 82.8 \\
\hline 9 & $\begin{array}{l}\text { Bernstein DP, Stein JA, Newcomb MD, Walker E, Pogge D, Ahluvalia T, Stokes J, Handelsman L, Medrano M, Desmond D, } \\
\text { Zule W. Development and validation of a brief screening version of the Childhood Trauma Questionnaire. Child Abuse } \\
\text { and neglect. 2003;27:69-190 }\end{array}$ & 1320 & 88.0 \\
\hline 10 & $\begin{array}{l}\text { Angold A, Costello EJ, Erkanli A. Comorbidity. Journal of Child Psychology and Psychiatry and Applied Disciplines. } \\
\text { 1999;40:57-87 }\end{array}$ & 1315 & 69.2 \\
\hline 11 & $\begin{array}{l}\text { Prince M, Patel V, Saxena S, Maj M, Maselko J, Phillips MR, Rahman A. Global mental health 1—No health without mental } \\
\text { health. Lancet. 2007;370:859-877 }\end{array}$ & 1213 & 110.3 \\
\hline 12 & $\begin{array}{l}\text { Durlak JA, Weissberg RP, Dymnicki AB, Taylor RD, Schellinger KB. The Impact of Enhancing Students' Social and } \\
\text { Emotional Learning: A Meta-Analysis of School-Based Universal Interventions. Child Development. 2001;82:405-432 }\end{array}$ & 1169 & 167.0 \\
\hline 13 & $\begin{array}{l}\text { Hayes SC, Wilson KG, Gifford EV, Follette VM, Strosahl K. Experiential avoidance and behavioral disorders: A functional } \\
\text { dimensional approach to diagnosis and treatment. Journal of Consulting and Clinical Psychology. 1996;64:1152-1168 }\end{array}$ & 1147 & 52.1 \\
\hline
\end{tabular}


Table 5. Cont

\begin{tabular}{|c|c|c|c|}
\hline Rank & Paper & Total Citation & Citations/Year \\
\hline 14 & $\begin{array}{l}\text { Heim C, Newport DJ, Heit S, Graham YP, Wilcox M, Bonsall R, Miller AH, Nemeroff CB. Pituitary-adrenal and autonomic } \\
\text { responses to stress in women after sexual and physical abuse in childhood. JAMA Journal of the American Medical } \\
\text { Association. 200;284:592-597 }\end{array}$ & 1093 & 60.7 \\
\hline 15 & $\begin{array}{l}\text { Gilbert R, Widom CS, Browne K, Fergusson D, Webb E, Janson S. Child Maltreatment } 1 \text { Burden and consequences of child } \\
\text { maltreatment in high-income countries. Lancet. 2009;373:68-81 }\end{array}$ & 1091 & 121.2 \\
\hline 16 & $\begin{array}{l}\text { Anda RF, Felitti VJ, Bremner JD, Walker JD, Whitfield C, Perry BD, Dube SR, Giles WH. The enduring effects of abuse and } \\
\text { related adverse experiences in childhood—A convergence of evidence from neurobiology and epidemiology. European } \\
\text { Archives of Psychiatry and Clinical Neuroscience. 2006;256:174-186 }\end{array}$ & 1057 & 88.1 \\
\hline 17 & $\begin{array}{l}\text { Biederman J, Newcorn J, Sprich S. Comorbidity of attention-deficit hyperactivity disorder with conduct, depressive, } \\
\text { anxiety, and other disorders. American Journal of Psychiatry. 1999;148:564-577 }\end{array}$ & 1026 & 38.0 \\
\hline 18 & $\begin{array}{l}\text { Birmaher B, Ryan ND, Williamson DE, Brent DA, Kaufman J, Dahl RE, Perel J, Nelson B. Childhood and adolescent } \\
\text { depression: A review of the past } 10 \text { years. Journal of the American Academy of Child and Adolescent Psychiatry. } \\
\text { 1996;35:1427-1439 }\end{array}$ & 997 & 45.3 \\
\hline 19 & $\begin{array}{l}\text { Dishion TJ, McCord J, Poulin F. When interventions harm-Peer groups and problem behavior. American Psychologist. } \\
\text { 1999;54:755-764 }\end{array}$ & 956 & 50.3 \\
\hline 20 & $\begin{array}{l}\text { Brewin CR, Andrews B, Gotlib IH. Psychopathology and early experience-a reappraisal of retrospective reports. } \\
\text { Psychological Bulletin. 1993;113:82-98 }\end{array}$ & 941 & 37.6 \\
\hline 21 & Terr LC. Childhood traumas—an outline and overview. American Journal of Psychiatry. 1991;48:10-20 & 909 & 33.7 \\
\hline 22 & Barber BK. Parental psychological control: Revisiting a neglected construct. Child Development. 1996;67:3296-3319 & 902 & 41.0 \\
\hline 23 & $\begin{array}{l}\text { Straus MA, Hamby SL, Finkelhor D, Moore DW, Runyan D. Identification of child maltreatment with the parent-child } \\
\text { Conflict Tactics Scales: Development and psychometric data for a national sample of American parents. Child Abuse and } \\
\text { Neglect. 1998;22:249-270 }\end{array}$ & 860 & 43.0 \\
\hline 24 & Evans GW. The environment of childhood poverty. American Journal of Psychiatry. 2004;59:77-92 & 831 & 59.4 \\
\hline 25 & Shonkoff JP, Garner AS. The Lifelong Effects of Early Childhood Adversity and Toxic Stress. Pediatrics. 2012;129:E232-E246 & 821 & 136.8 \\
\hline 26 & $\begin{array}{l}\text { Moffitt TE, Caspi A, Harrington H, Milne BJ. Males on the life-course-persistent and adolescence-limited antisocial } \\
\text { pathways: Follow-up at age } 26 \text { years. Development and Psychopathology. 2002;14:179-207 }\end{array}$ & 816 & 51.0 \\
\hline 27 & $\begin{array}{l}\text { Ceci SJ, Bruck M. Suggestibility of the child witness-a historical review and synthesis. Psychological Bulletin. } \\
\text { 1993;113:403-439 }\end{array}$ & 801 & 32.0 \\
\hline
\end{tabular}


Table 5. Cont

\begin{tabular}{|c|c|c|c|}
\hline Rank & Paper & Total Citation & Citations/Year \\
\hline 28 & $\begin{array}{l}\text { Dube SR, Anda RF, Felitti VJ, Chapman DP, Williamson DF, Giles WH. Childhood abuse, household dysfunction, and the } \\
\text { risk of attempted suicide throughout the life span-Findings from the adverse childhood experiences study. JAMA Journal } \\
\text { of the American Medical Association. 2001;286:3089-3096 }\end{array}$ & 794 & 46.7 \\
\hline 29 & $\begin{array}{l}\text { Beithchman JH; Zucker KJ; Hood JE; Dacosta GA; Akman D; Cassavia, E. A review of the long-term effects of child sexual } \\
\text { abuse. Child Abuse and Neglect. 1992;16:101-118 }\end{array}$ & 791 & 30.4 \\
\hline 30 & $\begin{array}{l}\text { Bar-on ME, Broughton DD, Buttross S, Corrigan S, Gedissman A, de Rivas MRG, Rich M, Shifrin DL. Children, adolescents, } \\
\text { and television. Pediatrics. 2001;107:423-426 }\end{array}$ & 772 & 45.4 \\
\hline 31 & $\begin{array}{l}\text { Shaffer D, Gould MS, Fisher P, Trautman P, Moreau D; Kleinman M; Flory M. Psychiatric diagnosis in child and adolescent } \\
\text { suicide. Archives of General Psychiatry. 1996;53:339-348 }\end{array}$ & 760 & 34.5 \\
\hline 32 & $\begin{array}{l}\text { Walker SP, Wachs TD, Gardner JM, Lozoff B, Wasserman GA, Pollitt E, Carter JA. Child development in developing } \\
\text { countries 2-Child development: risk factors for adverse outcomes in developing countries. Lancet. 2007;369:145-157 }\end{array}$ & 753 & 68.5 \\
\hline 33 & $\begin{array}{l}\text { Anderson CA, Bushman BJ. Effects of violent video games on aggressive behavior, aggressive cognition, aggressive affect, } \\
\text { physiological arousal, and prosocial behavior: A meta-analytic review of the scientific literature. Psychological Science. } \\
\text { 2001;12:353-359 }\end{array}$ & 749 & 44.1 \\
\hline 34 & $\begin{array}{l}\text { Finkelhor D; Browne A. The traumatic impact of child sexual abuse-a conceptualization. American Journal of } \\
\text { Orthopsychiatry. 1985;55:530-541 }\end{array}$ & 740 & 22.4 \\
\hline 35 & $\begin{array}{l}\text { Salmivalli C, Lagerspetz K, Bjorkqvist K, Osterman K, Kaukiainen A. Bullying as a group process: Participant roles and } \\
\text { their relations to social status within the group. Aggressive Behavior. 1996;22:1-15 }\end{array}$ & 719 & 32.7 \\
\hline 36 & Loftus EF. The reality of repressed memories. American Psychologist. 1993;18:518-537 & 711 & 28.4 \\
\hline 37 & $\begin{array}{l}\text { Read, J; van Os, J; Morrison, AP; Ross, CA. Childhood trauma, psychosis and schizophrenia: a literature review with } \\
\text { theoretical and clinical implications. Acta Psychiatrica Scandinavica. 2005;112:330-350 }\end{array}$ & 706 & 54.3 \\
\hline 38 & $\begin{array}{l}\text { Herman, JL. Complex PTSD—a syndrome in survivors of prolonged and repeated trauma. Journal of Traumatic Stress. } \\
\text { 1992;5:377-391 }\end{array}$ & 704 & 27.1 \\
\hline 39 & $\begin{array}{l}\text { Binder, EB et al. Association of FKBP5 polymorphisms and childhood abuse with risk of posttraumatic stress disorder } \\
\text { symptoms in adults. JAMA Journal of the American Medical Association. 2008; 299:1291-1305 }\end{array}$ & 690 & 69.0 \\
\hline 40 & $\begin{array}{l}\text { Olds, DL et al. Long-term effects of home visitation on maternal life course and child abuse and neglect-Fifteen-year } \\
\text { follow-up of a randomized trial. JAMA Journal of the American Medical Association. 1997;278:1291-1305 }\end{array}$ & 684 & 32.6 \\
\hline 41 & Belsky, J. Child maltreatment—an ecological integration. American Psychologist. 1980;35:320-335 & 670 & 17.6 \\
\hline
\end{tabular}


Table 5. Cont

\begin{tabular}{|c|c|c|c|}
\hline Rank & Paper & Total Citation & Citations/Year \\
\hline 42 & $\begin{array}{l}\text { Molnar, BE; Buka, SL; Kessler, RC. Child sexual abuse and subsequent psychopathology: Results from the National } \\
\text { Comorbidity Survey. American Journal of Public Health. 2001;91:753-760 }\end{array}$ & 639 & 37.6 \\
\hline 43 & $\begin{array}{l}\text { McCauley, J et al. Clinical characteristics of women with a history of childhood abuse-Unhealed wounds. JAMA Journal } \\
\text { of the American Medical Association 1997;277:1362-1368 }\end{array}$ & 628 & 29.9 \\
\hline 44 & $\begin{array}{l}\text { Kim-Cohen, J. MAOA, maltreatment, and gene-environment interaction predicting children's mental health: new evidence } \\
\text { and a meta-analysis. Molecular Psychiatry. 2006;11:903-913 }\end{array}$ & 614 & 51.2 \\
\hline 45 & Belsky, J. Etiology of child maltreatment—a developmental ecological analysis. Psychological Bulletin. 1983;114:413-434 & 611 & 17.5 \\
\hline 46 & $\begin{array}{l}\text { Putnam, FW. Ten-year research update review: Child sexual abuse. Journal of the American Academy of Child and } \\
\text { Adolescent Psychiatry. 2003;42:269-278 }\end{array}$ & 609 & 40.6 \\
\hline 47 & $\begin{array}{l}\text { Margolin, G; Gordis, EB. The effects of family and community violence on children. Annual Review of Psychology. } \\
\text { 2000;51:445-479 }\end{array}$ & 606 & 33.7 \\
\hline 48 & Krug, EG; Mercy, JA; Dahlberg, LL; Zwi, AB. The world report on violence and health. Lancet. 2002;360:1083-1088 & 601 & 37.6 \\
\hline
\end{tabular}




\section{Discussion}

In this scientometrics research, we focused on analyzing the international science and scientific reports on child maltreatment during the period 1916-2018 (May 2018). We have recognized the most dynamic authors and countries, most frequent subject areas, as well as common keywords, most productive journals, and citation reports in child abuse and maltreatment, based on the research publications on the Web of Science Core Collection. There have been an increasing number of published items in the last decades, with more than half of the reports published since 2010. To the best of our understanding, this can be considered the first inclusive global mapping and analysis of scientific research papers in child maltreatment. In agreement with some research in different areas, our research has also confirmed that the United States was the science hub of knowledge-sharing and the global leader in research publications in this discipline [23,24], followed by the countries in Western Europe (such as England, the Netherlands and Germany), Canada and Australia. The large amount of research on child abuse from these countries reflects the huge concern that the Western world has dedicated to find the means and prevalence of child abuse, as well as the effects of child maltreatment on youth society. Additionally, it reflects that awareness of child abuse is on the rise. However, some reports showed that the trend of child abuse was "not a true increase in prevalence but due to the changes in legislation" $[25,26]$. In another context, some researchers found that there were no changes in the rate of child physical abuse $[27,28]$, even though there was a rise in the prevalence of child emotional abuse [28].

The most powerful collaborations worldwide occurred among authors and organizations from the United States, England and Canada. We predicted the limited contribution of the authors in low-and-middle-income countries, especially in Asia, partly due to the concept of societies that considered child sexual abuse as "sensitive and taboo" and partly due to the adult's conceptualization of the need of child punishment for raising children [29,30]. For example, in India, child sexual abuse was historically a hidden problem and usually ignored by the public [31]. This public health problem was brought to international attention only since 1988 [32]. In 2012, a new Bill on the 'Protection of Children from Sexual Offences' became an Act [31]. In developed countries, governments took a leadership role early on, such as the U.S Congress passing the "Child Abuse Prevention and Treatment Act" (CAPTA) in 1974, and in England the "Children Act 1989" provided the legislative framework for child protection and was later strengthened by the Children Act 2004. Another valuable example here is in European countries. Although each European country has different political systems, the countries share a common mission: child protection. At the European Union (EU) level, the European children's rights law was submitted by the Council of Europe ( $\mathrm{CoE})$ and the EU. Recently, children's rights have been considered as an important issue which needs more cooperation [33]. One explanation for such a discrepancy among geo-social regions could be the variation in mindsets among the people. For example, in India, there are a number of deep-rooted socio-culture elements; gender discrimination caused by male child preference being the most worrisome one [34]. Another noteworthy example that can be considered is corporal punishment, which differs among countries' cultures and child-rearing practices. According to a research paper with a sample of nine countries, the use of corporal punishment on children was lowest by Swedish parents and highest by Kenyan parents [35]. A similar pattern has been observed with Southeast Asian countries; there is a cultural norm in Vietnamese parents: "spare the rod, spoil the child" and they usually use harsh discipline to raise a well-mannered child [36].

Journals that published the most papers related to child maltreatment were Child Abuse \& Neglect and Children and Youth Services Review. In fact, the most commented-upon topic of child maltreatment was child neglect, and it can be explained that this is the most common form of child maltreatment [37]. Our analysis revealed that nearly $51.6 \%$ of all scientific papers were published in the research discipline of psychology and family studies. A large number of papers in psychology and family studies could be attributed to the view that family education is important to prevent child abuse [38] and/or the child's normal emotional development is interrupted due to abuse 
victimization [39]. Therefore, in this topic, the development of psychology can bring a positive impact on increasing research and intervention [40]. Our study concludes that child maltreatment has triggered a deep concern among research authors, who performed research in various disciplines, from Government Law [41,42], Social Sciences [43], Criminology Penology [44], Neurosciences [45], to General Internal Medicine [46-48]. The authors' keywords co-occurrence analysis has explained the level of concern about this topic. For example, "child abuse" was the most regular keyword that has strong connection to common types of child maltreatment: sexual abuse, physical abuse, and neglect. Besides, "domestic violence" (among parents or other family members) with the child witnessing was also considered child abuse, as it has direct the effects on the child's overall development [49]. The number of papers in child protection, intervention, and child abuse prevention contributed a small number compared with that of child abuse or child maltreatment. Likewise, the epidemiology of child maltreatment was more readily found in high-income countries than in low-and-middle-income countries (LMICs). Our result has been in line with the report prepared by the United Nations Children Fund (UNICEF), in which stress has been found to be empirically associated with child abuse, and alcohol and substance abuse have contributed to the higher risk [50].

The list of most cited research articles showed us the research interest in topics on child maltreatment. The effects of child maltreatment [51-53] and research about child abuse and violence $[54,55]$ attracted audiences to the authors the most. However, there is a huge knowledge gap in these research fields [56,57], such as the effectiveness of child abuse and neglect interventions, especially in low-and-middle-income countries (LMICs). Despite the fact that the developed countries have over 30 years of trend in evaluating the effectiveness of intervention programs, the knowledge may not be relevant or applicable in LMICs. Part of the reason can be the priority that the LMICs' governments set for spending to adapt basic needs (food supply, electricity or water) and reduce poverty and crime or the lack of investment in research and development (R\&D). Thus, LMICs may have adapted the intervention model of high-income countries without adequate or necessary and sufficient conditions for successful interventions. From our point of view, LMICs have advantages when they can inherit some useful models from high-income countries, provided they train local experts to the extent that professionals carefully appreciate the cultures and efficiently connect to the knowledge hubs.

We must discuss some weakness and limitations of our study. First, the Web of Science database was the only one we used to generate the scientific papers, including the characteristics of the data (such as the number of records, publication year or authors) and for examining the network of keywords and international collaboration. However, articles that belong to open access data not provided by the Web of Science may affect the search results [58]. Secondly, the analysis of keywords co-occurrence depends on the chosen keywords; and this can be a source of bias toward a cohort of the Web of Science-indexed papers.

Thirdly, due to the vastly different definitions of child abuse and neglect in different organizations and countries, it is sometimes difficult to choose the one which can satisfactorily cover all forms of child maltreatment. For example, the types of child abuse and neglect are recognized differently by different States in the United States. Although most States recognize physical abuse, neglect, sexual abuse, and emotional abuse, some states also consider parental substance abuse and/or child abandonment as forms of child abuse [59]. Besides, with the rapid development of technology, a new form of child abuse has recently been mentioned in a report of the National Society for the Prevention of Cruelty to Children (NSPCC): online abuse [60]. In addition, UNICEF and INSPIRE program (WHO) reports show that there are some forms of violence which are harmful to children that are outside of the child abuse definition, such as child bullying, children in armed conflict, child soldiers, or the homicide of street children $[8,16]$. More than that, in the form of foster care, children may have suffered some forms of maltreatment and some characteristics are identified to predict the risks [61]. What we followed was the WHO report that has defined four types of child maltreatment: child sexual abuse, child physical abuse, child emotional abuse and child psychological abuse [1]. Besides, we performed the search 
query by applying the notions of child violence, child trafficking and child grooming [21,22]. As we did not use previously mentioned words, our search results may be not fully adequate. Therefore, there is a need for more cooperation among researchers, organizations, and governments to reach a more 'universal' and 'generally accepted' definition of this serious social problem.

As we included only research articles and reviews, a significant number of important reports, such as progress reports, annual reports of governments, books or book chapters, and guidance from governments representing an excellent contribution to the to the topic of child abuse and violence should also be considered for a more complete evaluation $[59,60,62]$. Human language is extremely diverse [63], but we included only English articles and reviews in our study; thus, non-English research papers in Europe, Asia or Africa are not counted. That made the number of Western countries' publications, especially in English speaking ones, more than that of the Asia or Africa regions. Finally, although we have tried to control the quality of the research results by reading titles and abstracts only, sometimes there are papers with less relevant contents still appearing in the review workload. Fortunately, they only count a small fraction and should not seriously affect the results. Having appreciated the attention from not only the scientific circles, but also the public, governments and educators, we conclude that this topic in the coming years will be high on various agendas, with a strong emphasis being given on the highly practical subfields of prevention and intervention of child maltreatment.

\section{Conclusions}

The scientometrics analysis has provided highly relevant data for evaluating the growth of scientific research on child maltreatment. The number of research papers published has been increasing with the most influential knowledge and ideas coming from Western countries; notably, the United States has led the trend. This research made a contribution to the extant literature regarding this important social problem, and recognized the main research areas, publications and leading scientific authors and countries. Development in research methods and extension in the research areas will allow for the evaluating of relevant research methods, and would likely contribute to child abuse prevention, as well as future agendas for the cause of public health improvements.

Supplementary Materials: The following are available online at http:/ /www.mdpi.com/1660-4601/15/7/1456/ s1, Table S1: Search Strategy, Table S2: Top 100 prolific authors, Table S3: Top 100 prolific countries.

Author Contributions: Conceptualization, L.H.N. and T.T.T.; Data curation, B.X.T., G.H.H., A.T.N., T.T.M.V., H.N.D., A.T.L.N., T.T.T., N.T.T., V.Q.H., T.T.V., H.Q.N., H.T.L., M.M., M.D., S.S.A., T.H.N., S.B. and R.C.M.H.; Formal analysis, B.X.T., T.V.P., L.H.N., T.T.M.V., H.N.D., V.N., T.M.H., T.T.V., Y.S., S.S.A., C.A.L. and R.C.M.H.; Funding acquisition, B.X.T., T.V.P., G.H.H., L.H.N., T.T.M.V., H.N.D., V.N., A.T.L.N., N.V.D., H.T.L., H.T.D., M.M., Y.S., T.H.N., S.B., C.A.L. and C.S.H.H.; Investigation, B.X.T., T.V.P., A.T.N., T.T.M.V., H.N.D., V.N., A.T.L.N., N.T.T., V.Q.H., T.M.H., N.V.D., T.T.V., H.Q.N., H.T.L., H.T.D., M.M., M.D., S.S.A., T.H.N., S.B. and C.S.H.H.; Methodology, V.N., T.T.T., N.T.T., V.Q.H., T.M.H., N.V.D., H.Q.N., M.M., Y.S., S.S.A., T.H.N., S.B., C.A.L. and C.S.H.H.; Project administration, T.V.P., A.T.N., H.N.D., A.T.L.N., N.T.T., V.Q.H., T.T.V., H.T.L., H.T.D., M.M., Y.S. and R.C.M.H.; Resources, A.T.N., L.H.N., V.Q.H., N.V.D., M.D., T.H.N., S.B. and R.C.M.H.; Software, T.V.P., G.H.H., A.T.N., T.T.M.V., N.T.T., N.V.D., H.T.D., M.D. and S.S.A.; Supervision, B.X.T., V.N., T.T.T., T.M.H., T.T.V., H.Q.N., C.A.L., C.S.H.H. and R.C.M.H.; Validation, A.T.L.N., T.M.H., Y.S., C.A.L. and C.S.H.H.; Visualization, G.H.H., L.H.N., T.T.T., H.Q.N. and H.T.D.; Writing-original draft, G.H.H., H.T.L. and M.D.; Writing-review \& editing, B.X.T., T.V.P., G.H.H., A.T.N., L.H.N., T.T.M.V., H.N.D., V.N., A.T.L.N., T.T.T., N.T.T., V.Q.H., T.M.H., N.V.D., T.T.V., H.Q.N., H.T.L., H.T.D., M.M., Y.S., M.D., S.S.A., T.H.N., S.B., C.A.L., C.S.H.H. and R.C.M.H.

Funding: This research received no external funding.

Conflicts of Interest: The authors declare no conflict of interest.

\section{References}

1. Butchart, A.; Harvey, A.P. Preventing Child Maltreatment: A Guide to Taking Action and Generating Evidence. Available online: http://www.who.int/violence_injury_prevention/publications/violence/ child_maltreatment/en/ (accessed on 3 June 2018). 
2. Krug, E.G.; Mercy, J.A.; Dahlberg, L.L.; Zwi, A.B. World Report on Violence and Health; World Health Organization: Geneva, Switzerland, 2002.

3. Committee on Child Maltreatment Research, Policy, and Practice for the Next Decade: Phase II; Board on Children, Youth, and Families; Committee on Law and Justice; Institute of Medicine; National Research Council. New Directions in Child Abuse and Neglect Research; Petersen, A.C., Joseph, J., Feit, M., Eds.; National Academies Press: Washington, DC, USA, 2004. [CrossRef]

4. Middlebrooks, J.S.; Audage, N.C. The Effects of Childhood Stress on Health across the Lifespan; Centers for Disease Control and Prevention, Ed.; National Center for Injury Prevention and Control: Atlanta, GA, USA, 2008.

5. Kolko, D.J. Characteristics of child victims of physical violence: Research findings and clinical implications. J. Interpers. Violence 1992, 7, 244-276. [CrossRef]

6. Perez, C.M.; Widom, C.S. Childhood victimization and long-term intellectual and academic outcomes. Child Abuse Negl. 1994, 18, 617-633. [CrossRef]

7. Fergusson, D.M.; Boden, J.M.; Horwood, L.J. Exposure to childhood sexual and physical abuse and adjustment in early adulthood. Child Abuse Negl. 2008, 32, 607-619. [CrossRef] [PubMed]

8. United Nations Children's Fund. A Familiar Face: Violence in the Lives of Children and Adolescents; United Nation's Children's Fund: New York, NY, USA, 2017.

9. Finkelhor, D.; Shattuck, A.; Turner, H.A.; Hamby, S.L. The Lifetime Prevalence of Child Sexual Abuse and Sexual Assault Assessed in Late Adolescence. J. Adolesc. Health 2013, 55, 329-333. [CrossRef] [PubMed]

10. Gorey, K.; Leslie, D. The prevalence of child sexual abuse: Integrative review adjustment for potential response and measurement biases. Child Abuse Negl. 1997, 21, 391-398. [CrossRef]

11. Stoltenborgh, M.; van Ijzendoorn, M.H.; Euser, E.M.; Bakermans-Kranenburg, M.J. A global perspective on child abuse: Meta-analysis of prevalence around the world. Child Maltreat. 2011, 16, 79-101. [CrossRef] [PubMed]

12. Pereda, N.; Guilera, G.; Forns, M.; Gómez-Benito, J. The prevalence of child sexual abuse in community and student samples: A meta-analysis. Clin. Psychol. Rev. 2009, 29, 328-338. [CrossRef] [PubMed]

13. Naidoo, S. A profile of the oro-facial injuries in child physical abuse at a children's hospital. Child Abuse Negl. 2000, 24, 521-534. [CrossRef]

14. Kraus, C.; Jandl-Jager, E. Awareness and knowledge of child abuse amongst physicians-A descriptive study by a sample of rural Austria. Wien. Klinische Wochenschr. 2011, 123, 340-349. [CrossRef] [PubMed]

15. AlBuhairan, F.S.; Inam, S.S.; AlEissa, M.A.; Noor, I.K.; Almuneef, M.A. Self reported awareness of child maltreatment among school professionals in Saudi Arabia: Impact of CRC ratification. Child Abuse Negl. 2011, 35, 1032-1036. [CrossRef] [PubMed]

16. World Health Organization. INSPIRE: Seven Strategies for Ending Violence against Children; World Health Organization: Luxembourg, 2016.

17. United Nations Children's Fund (UNICEF). Child Marriage and the Law; United Nations Children's Fund (UNICEF): New York, NY, USA, 2008.

18. Cutland, M. Child abuse and its legislation: The global picture. Arch. Dis. Child. 2012, 97, 679-684. [CrossRef] [PubMed]

19. Agarwal, A.; Durairajanayagam, D.; Tatagari, S.; Esteves, S.C.; Harlev, A.; Henkel, R.; Roychoudhury, S.; Homa, S.; Puchalt, N.G.; Ramasamy, R.; et al. Bibliometrics: Tracking research impact by selecting the appropriate metrics. Asian J. Androl. 2016, 18, 296-309. [CrossRef] [PubMed]

20. Haugaard, J.J. The challenge of defining child sexual abuse. Am. Psychol. 2000, 55, 1036-1039. [CrossRef] [PubMed]

21. Craven, S.; Brown, S.; Gilchrist, E. Sexual grooming of children: Review of literature and theoretical considerations. J. Sex. Aggress. 2006, 12, 287-299. [CrossRef]

22. Greenbaum, J.; Bodrick, N. Global Human Trafficking and Child Victimization. Pediatrics $2017,140$. [CrossRef] [PubMed]

23. Kusma, B.; Scutaru, C.; Quarcoo, D.; Welte, T.; Fischer, T.C.; Groneberg-Kloft, B. Tobacco control: Visualisation of research activity using density-equalizing mapping and scientometric benchmarking procedures. Int. J. Environ. Res. Public Health 2009, 6, 1856-1869. [CrossRef] [PubMed]

24. Biglu, M.H.; Abotalebi, P.; Ghavami, M. Breast cancer publication network: Profile of co-authorship and co-organization. BioImpacts BI 2016, 6, 211-217. [CrossRef] [PubMed] 
25. Paine, C.W.; Fakeye, O.; Christian, C.W.; Wood, J.N. Prevalence of Abuse among Young Children with Rib Fractures: A Systematic Review. Pediatr. Emerg. Care 2016. [CrossRef] [PubMed]

26. Miller-Graff, L.E.; Howell, K.H.; Martinez-Torteya, C.; Grein, K. Direct and Indirect Effects of Maltreatment and Social Support on Children's Social Competence Across Reporters. Child Psychiatry Hum. Dev. 2017, 48, 741-753. [CrossRef] [PubMed]

27. Feldman, W.; Feldman, E.; Goodman, J.T.; McGrath, P.J.; Pless, R.P.; Corsini, L.; Bennett, S. Is childhood sexual abuse really increasing in prevalence? An analysis of the evidence. Pediatrics 1991, 88, 29-33. [CrossRef]

28. Witt, A.; Glaesmer, H.; Jud, A.; Plener, P.L.; Brahler, E.; Brown, R.C.; Fegert, J.M. Trends in child maltreatment in Germany: Comparison of two representative population-based studies. Child Adolesc. Psychiatry Ment. Health 2018, 12, 24. [CrossRef] [PubMed]

29. Veenema, T.G.; Thornton, C.P.; Corley, A. The public health crisis of child sexual abuse in low and middle income countries: An integrative review of the literature. Int. J. Nurs. Stud. 2015, 52, 864-881. [CrossRef] [PubMed]

30. Cappa, C.; Dam, H. Prevalence of and risk factors for violent disciplinary practices at home in Viet Nam. J. Interpers. Violence 2014, 29, 497-516. [CrossRef] [PubMed]

31. Belur, J.; Singh, B.B. Child sexual abuse and the law in India: A commentary. Crime Sci. 2015, 4, 26. [CrossRef]

32. Segal, U.A. Child abuse in India: An empirical report on perceptions. Child Abuse Negl. 1992, 16, 887-908. [CrossRef]

33. Council of Europe; European Union. Handbook on European Law Relating to the Rights of the Child; Publications Office of the European Union: Belgium, Brussels, 2018; pp. 17-22. [CrossRef]

34. Singhi, P.; Saini, A.G.; Malhi, P. Child maltreatment in India. Paediatr. Int. Child Health 2013, 33, $292-300$. [CrossRef] [PubMed]

35. Lansford, J.E.; Alampay, L.P.; Al-Hassan, S.; Bacchini, D.; Bombi, A.S.; Bornstein, M.H.; Chang, L.; Deater-Deckard, K.; Di Giunta, L.; Dodge, K.A.; et al. Corporal punishment of children in nine countries as a function of child gender and parent gender. Int. J. Pediatr. 2010, 2010, 672780. [CrossRef] [PubMed]

36. Beazley, H.; Bessell, S.; Ennew, J.; Waterson, R. What Children Say: Results of a Comparative Research on the Physical and Emotional Punishment of Children in South East Asia and the Pacific, 2005; Save the Children: Stockholm, Sweden, 2006.

37. Leventhal, J.M.; Gaither, J.R. Incidence of serious injuries due to physical abuse in the United States: 1997 to 2009. Pediatrics 2012, 130, e847-e852. [CrossRef] [PubMed]

38. Farst, K.; Ambadwar, P.B.; King, A.J.; Bird, T.M.; Robbins, J.M. Trends in hospitalization rates and severity of injuries from abuse in young children, 1997-2009. Pediatrics 2013, 131, e1796-e1802. [CrossRef] [PubMed]

39. Marion, M. Primary Prevention of Child Abuse: The Role of the Family Life Educator. Fam. Relat. 1982, 31, 575-582. [CrossRef]

40. Cicchetti, D.; Toth, S. Developmental Psychopathology Perspective on Child-Abuse and Neglect. J. Am. Acad. Child Adolesc. Psychiatry 1995, 34, 541-565. [CrossRef] [PubMed]

41. Peixoto, C.E.; Fernandes, R.V.; Almeida, T.S.; Silva, J.M.; La Rooy, D.; Ribeiro, C.; Magalhães, T.; Lamb, M.E. Interviews of Children in a Portuguese Special Judicial Procedure. Behav. Sci. Law 2017, 35, 189-203. [CrossRef] [PubMed]

42. Dickinson, J.J.; Poole, D.A. The influence of disclosure history and body diagrams on children's reports of inappropriate touching: Evidence from a new analog paradigm. Law Hum. Behav. 2017, 41, 1. [CrossRef] [PubMed]

43. Wurtele, S.K.; Simons, D.A.; Parker, L.J. Understanding Men's Self-Reported Sexual Interest in Children. Arch. Sex. Behav. 2018. [CrossRef] [PubMed]

44. Zhu, Y.; Chan, K.L.; Chen, J. Bullying Victimization among Chinese Middle School Students: The Role of Family Violence. J. Interpers. Violence 2018, 33, 1958-1977. [CrossRef] [PubMed]

45. Brodbeck, J.; Fassbinder, E.; Schweiger, U.; Fehr, A.; Späth, C.; Klein, J.P. Differential associations between patterns of child maltreatment and comorbidity in adult depressed patients. J. Affect. Disord. 2018, 230, 34-41. [CrossRef] [PubMed]

46. Heim, C.; Newport, D.J.; Heit, S.; Graham, Y.P.; Wilcox, M.; Bonsall, R.; Miller, A.H.; Nemeroff, C.B. Pituitary-adrenal and autonomic responses to stress in women after sexual and physical abuse in childhood. JAMA 2000, 284, 592-597. [CrossRef] [PubMed] 
47. Gilbert, R.; Widom, C.S.; Browne, K.; Fergusson, D.; Webb, E.; Janson, S. Burden and consequences of child maltreatment in high-income countries. Lancet 2009, 373, 68-81. [CrossRef]

48. Dube, S.R.; Anda, R.F.; Felitti, V.J.; Chapman, D.P.; Williamson, D.F.; Giles, W.H. Childhood abuse, household dysfunction, and the risk of attempted suicide throughout the life span: Findings from the Adverse Childhood Experiences Study. JAMA 2001, 286, 3089-3096. [CrossRef] [PubMed]

49. Callaghan, J.E.; Alexander, J.H.; Sixsmith, J.; Fellin, L.C. Beyond “Witnessing": Children's Experiences of Coercive Control in Domestic Violence and Abuse. J. Interpers. Violence 2015. [CrossRef] [PubMed]

50. Rao, S.; Lux, A.L. The epidemiology of child maltreatment. Paediatr. Child Health 2012, 22, 459-464. [CrossRef]

51. Anda, R.F.; Felitti, V.J.; Bremner, J.D.; Walker, J.D.; Whitfield, C.; Perry, B.D.; Dube, S.R.; Giles, W.H. The enduring effects of abuse and related adverse experiences in childhood. A convergence of evidence from neurobiology and epidemiology. Eur. Arch. Psychiatry Clin. Neurosci. 2006, 256, 174-186. [CrossRef] [PubMed]

52. Beitchman, J.H.; Zucker, K.J.; Hood, J.E.; daCosta, G.A.; Akman, D.; Cassavia, E. A review of the long-term effects of child sexual abuse. Child Abuse Negl. 1992, 16, 101-118. [CrossRef]

53. Browne, A.; Finkelhor, D. Impact of child sexual abuse: A review of the research. Psychol. Bull. 1986, 99, 66-77. [CrossRef] [PubMed]

54. Putnam, F.W. Ten-year research update review: Child sexual abuse. J. Am. Acad. Child Adolesc. Psychiatry 2003, 42, 269-278. [CrossRef] [PubMed]

55. Molnar, B.E.; Buka, S.L.; Kessler, R.C. Child sexual abuse and subsequent psychopathology: Results from the National Comorbidity Survey. Am. J. Public Health 2001, 91, 753-760. [PubMed]

56. Macdonald, G. Effective Interventions for Child Abuse and Neglect: An Evidence-Based Approach to Planning and Evaluating Interventions; Wiley \& Sons, Ltd.: New York, NY, USA, 2001.

57. Pecora, P.J.; Sanders, D.; Wilson, D.; English, D.; Puckett, A.; Rudlang-Perman, K. Addressing common forms of child maltreatment: Evidence-informed interventions and gaps in current knowledge. Child Fam. Soc. Work 2012, 19, 321-332. [CrossRef]

58. Falagas, M.E.; Pitsouni, E.I.; Malietzis, G.A.; Pappas, G. Comparison of PubMed, Scopus, Web of Science, and Google Scholar: Strengths and weaknesses. FASEB J. 2008, 22, 338-342. [CrossRef] [PubMed]

59. Bureau, C.S. Child Maltreatment 2015: Summary of Key Findings. Available online: https://www. childwelfare.gov/pubs/factsheets/canstats / (accessed on 3 June 2018).

60. How Safe Are Our Children? The Most Comprehensive Overview of Child Protection in the UK 2017. Available online: https:/ / www.nspcc.org.uk/globalassets/documents/research-reports/how-safe-children2017-report.pdf (accessed on 3 June 2018).

61. Zuravin, S.J.; Benedict, M.; Somerfield, M. Child maltreatment in family foster care. Am. J. Orthopsychiatry 1993, 63, 589-596. [CrossRef] [PubMed]

62. Child Maltreatment 2016. Available online: https://www.acf.hhs.gov/cb/resource/child-maltreatment2016 (accessed on 3 June 2018).

63. Fitch, W.T. Unity and diversity in human language. Philos. Trans. R. Soc. Lond. Ser. B Biol. Sci. 2011, 366, 376-388. [CrossRef] [PubMed]

(C) 2018 by the authors. Licensee MDPI, Basel, Switzerland. This article is an open access article distributed under the terms and conditions of the Creative Commons Attribution (CC BY) license (http://creativecommons.org/licenses/by/4.0/). 